\title{
The Troubled Asset Relief Program (TARP) And The Financial Crisis Of 2007-2008
}

\author{
Anh Phuong Nguyen, New Mexico State University, USA
}

Carl E. Enomoto, New Mexico State University, USA

\begin{abstract}
When the financial crisis that started in the summer of 2007 took a turn for the worse in the fall of 2008, the Fed and Treasury Department engaged in efforts to stabilize financial markets. The Fed continuously reduced the discount rate and made loans to AIG, JPMorgan Chase, Morgan Stanley and Goldman Sachs. The U.S. Treasury Department initiated the Troubled Asset Relief Program (TARP), which many felt was a waste of federal dollars. Using a GARCH $(1,1)$ model, this paper finds evidence that volatility in stock index returns was reduced after October 14, 2008 when the TARP Capital Purchase Program was announced.
\end{abstract}

Keywords: TARP, financial crisis, volatility, GARCH, stabilization

\section{INTRODUCTION}

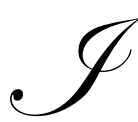

n 2008, U.S. financial markets were on the verge of collapse. The Dow Jones Industrial Average which stood at $14,164.53$ on October 8, 2007, closed at 7,552.29 on November 20, 2008. For all of 2008, the DJIA fell by $33.84 \%$, its largest percent decline since 1931 (The S\&P 500 Index fell by $38.5 \%$ in 2008).

A series of bankruptcies and acquisitions have also occurred throughout the past year. Block $(2008$, p. 1) stated: The Federal Deposit Insurance Corporation seized the assets of Washington Mutual, the nation's largest savings and loan, and brokered the sale of the company to JPMorgan Chase. The collapse of Washington Mutual-often called WaMu--is the largest bank failure in U.S. history."

Merrill Lynch and Countrywide Financial Corporation were acquired by Bank of America. Bear Stearns was bought out by JPMorgan Chase and Fannie Mae and Freddie Mac were placed in conservatorship under the Federal Housing Finance Agency. Lehman Brothers went bankrupt.

Much has been written about this financial crisis. Starting with the housing boom, rising home prices and subprime mortgages, the stage was set for a series of disastrous events that would create volatility in stock markets seldom experienced. The Fed and the U.S. Treasury Department actively pursued policies to stabilize financial markets. In particular, the U.S. Treasury department initiated TARP, the Troubled Asset Relief Program, to inject capital into banks with troubled assets. The Fed provided loans to JPMorgan Chase to help in the buyout of Bear Stearns and to Bank of America to acquire Merrill Lynch. The Fed also provided loans to AIG (American International Group) and the U.S. government received an equity stake in the company (Karnitschnig, Solomon , Pleven, and Hilsenrath, 2008, p. 1).

The purpose of this paper is to determine if Fed and Treasury policies have in fact, stabilized financial markets during the financial crisis of 2007-2008. The results will shed light on the usefulness of further intervention given forecasts of a prolonged and deep recession. The outline of this paper is as follows. In the next section, an overview of the financial crisis of 2007-2008 will be presented. The traditional stock valuation model will be presented, followed by a methodology and data section. Finally, the empirical results and conclusions will be summarized. 


\section{AN OVERVIEW OF THE FINANCIAL CRISIS OF 2007-2008}

In 1999, the S\&P 500 Index increased by $19.53 \%$. It would fall over the next 3 years by $10.14 \%$ in 2000 , $13.04 \%$ in 2001 , and $23.37 \%$ in 2002 . The U.S. economy officially entered a recession starting in March 2001 . The Fed reduced interest rates to stimulate the economy and by the summer of 2003, the Federal funds rate was at a record low according to Zandi (2000, p. 9). Mortgage rates also fell from 7\% in 2001 to $5.23 \%$ by 2003 (Waggoner (2008, p. 63)) and "By the end of 2003, home prices had gained 8\% nationwide, their best showing since 1953," (Waggoner, (2008, p. 22). With rising home prices, a purchase of a home became a good investment. Mortgage companies were even making loans to those with bad credit histories and low incomes. These subprime mortgages where often referred to as "liar loans" since the borrowers were not required to provide proof of the amount of income they were earning. Furthermore, many of these subprime mortgages were adjustable rate mortgages which came with a low "teaser" rate which would increase in a few years. The borrowers were often told by the mortgage companies that with the increase in the value of their home they could either sell the home and pay back the mortgage or refinance their mortgage at a lower rate. According to Brownell (2008, p. 51), "Thirty years ago subprime borrowers were basically out of luck. They couldn't get a loan. The government felt that subprime borrowers were being discriminated against. In reality the banks didn't want to loan them money because they were high risk and many of them wouldn't be able to repay the loans." The government insisted that financial institutions make loans to subprime borrowers and thus financial institutions found a way to make subprime mortgages profitable by selling them.

Fannie Mae, Freddie Mac and investment banks were purchasers of mortgages. Holmes (1999, p. 1) stated, "In a move that could help increase home ownership rates among minorities and low-income consumers, the Fannie Mae Corporation is easing the credit requirements on loans that it will purchase from banks and other lenders...Fannie Mae, the nation's biggest underwriter of home mortgages, has been under increasing pressure from the Clinton Administration to expand mortgage loans among low and moderate income people and felt pressure from stock holders to maintain its phenomenal growth in profits." After the mortgages were bought by Fannie Mae, Freddie Mac, and Wall Street firms, they were pooled together or packaged and used as collateral to create bonds called "mortgage backed securities" (MBSs) that paid interest to investors. These MBSs were sold to institutional investors such as insurance companies, pension funds, mutual funds, banks, cities, states, universities, endowment funds, and other investors (Brownell, 2008, p. 45). Zandi (2008) stated that with the U.S. trade deficit and with U.S. dollars going overseas to China, Russia, and the Middle East, many of these dollars were returning back to the U.S. to purchase Treasury bonds and MBSs.

In the period of rising home prices, 2000 to 2006, new homes were constantly being built and purchased by first time home owners and investors. Zandi (2008, p.15) stated, "House sales, construction, and prices were all shattering records. Prices more than doubled in such far-flung places as Providence, Rhode Island; Naples, Florida; Minneapolis, Minnesota; Tucson, Arizona; Salt Lake City, Utah; and Sacramento, California."

Zandi (2008, p. 16) further stated "...by mid 2004, the booming housing market and strong economy convinced policy makers it was time to throttle back by raising interest rates." According to Waggoner (2008, p. 63) mortgage rates went from 5.23\% in 2003 to $5.7 \%$ in 2005. By 2006, they were $6.41 \%$. These higher mortgage rates combined with high home prices new home buyers were facing, signaled the end of the housing boom. With the surplus of new homes that had been built and with the decline in home purchases caused by high mortgage rates and high home prices that potential buyers could not afford, home prices began to fall. Waggoner (2008, p. 61) stated, "The median price of a single-family home (half were higher, half were lower), hit $\$ 230,900$ in the third quarter of 2006 (National Association of Realtors). By November, the median price had slipped to $\$ 216,700$ and by the end of February 2008, \$195,600." Many homeowners were "underwater" with the value of their home less than their outstanding mortgage. Individuals who had taken out subprime mortgages with adjustable mortgage rates saw their mortgage rates and payments increasing and could not sell their home at a profit and could not refinance at a lower rate. Foreclosures on homes were increasing in 2006 and 2007 as home owners turned in their keys to their banks and walked away from their homes. Bernanke ((2009, p. 1) stated the following about the beginning of the financial credit crisis: "The severe disruption of credit markets that began late in the summer of 2007 and the associated tightening in credit conditions and declines in asset prices have weighed heavily on economic activity here and abroad." 
The mortgages that had been created and sold and resold were no longer generating the revenue that was once expected. Interest payments and principal to investors of MBSs were now in jeopardy. As a result, the value of MBSs fell. Insurance companies, pension funds, mutual funds, banks, foreign companies, and other investors in MBSs were now suffering losses. The investment banks who had purchased subprime mortgages were incurring losses. According to Waggoner (2008, p. 76), "In October (2007) Citigroup, the nation's largest bank, wrote down $\$ 2.2$ billion of subprime loans from its books." (Citigroup was one of the most active participants in the sub-prime mortgage-backed securities market). In November, Merrill Lynch stunned the financial community with a $\$ 7.9$ billion write down... In December, Bear Stearns was forced to write down $\$ 1.5$ billion in assets, and announced its first-ever quarterly loss." Zandi (2008, p. 6) further stated, "Bear Stearns bet big on the residential mortgage market. It not only issued mortgage securities, it had acquired mortgage lending firms that originated the loans that went into those securities." Bear Stearns also had hedge funds that invested in MBSs.

The Fed was concerned that the bankruptcy of Bear Stearns would destabilize financial markets. According to Waggoner (2008, p. 81), JPMorgan Chase ended up buying Bear Stearns' stock with the completion of the acquisition on May 30, 2008. Furthermore, "The Fed would lend \$10 billion to JPMorgan Chase, which would assume the first \$1 billion of losses from Bear Stearns' illiquid MBSs (Waggoner, (2008, p. 79))."

Taylor (2008, pp. 15-16) stated that the financial crisis worsened in the fall of 2008. He stated, "Many commentators have argued that the reason for the worsening of the crisis was the decision by the U.S. government (more specifically the Treasury and the Federal Reserve) not to intervene to prevent the bankruptcy of Lehman Brothers over the weekend of September 13 and 14. It is difficult to bring rigorous empirical analysis to this important question, but it is important that researchers do so because future policy actions depend on the answer. Perhaps the best empirical analyses we can hope for at this time are "event studies" that look carefully at reactions in the financial markets to various decisions and events." On September 15, 2008, the Dow Jones Industrial Average fell by 504 points, its largest one-day point drop in 2008 up to that day.

On October 3, 2008, the U.S. Congress enacted the Emergency Economic Stabilization Act under which the Troubled Asset Relief Program (TARP), including the Capital Purchase Program (CPP), was established. Initially, TARP funds were to be used by the Treasury to purchase mortgage backed securities from financial institutions to enable them to lend more to consumers and businesses. Instead, $\$ 250$ billion of the $\$ 700$ billion from the Emergency Economic Stabilization Act would be used for the Capital Purchase Program. Gorman (2008, p. 1) stated: "Under the Capital Purchase Program, Mr. Paulson announced that the U.S. Treasury would dedicate \$250 billion of the $\$ 700$ billion rescue package to the purchase of senior preferred stock to create high quality or "Tier 1 Capital" for banks. Along with the issuance of the senior preferred shares, participating financial institutions must issue to the US Treasury, warrants to purchase common stock..." The purpose of the Capital Purchase Program was to inject capital into the banking system to increase bank lending to consumers and businesses to stabilize financial markets.

The U.S. Treasury announced the TARP Capital Purchase Program on October 14, 2008 and the first purchases of the program took place on October 28, 2008. The Treasury has made available a full description of the allocation of all TARP funds at http://www.financialstability.gov. The first TARP purchases of October 28, 2008 included: $\$ 15$ billion to Bank of America Corporation for the purchase of preferred shares with warrants, $\$ 3$ billion to Bank of New York Mellon Corp., \$25 billion to Citigroup Inc., \$10 billion to the Goldman Sachs Group, \$25 billion to JPMorgan Chase \& Co., \$10 billion to Morgan Stanley, \$2 billion to State Street Corp., and \$25 billion to Wells Fargo \& Co. Remaining TARP purchases occurred throughout 2008 into 2009.

Liu (2009, p. 4-5) stated the following concerning TARP: "The TARP operates as a "revolving purchase facility." The Treasury has a set spending limit, $\$ 250$ billion at the start of the program, with which it purchased assets, and then either will sell them or hold the assets and collect the "coupons". The money received from sales and coupons is supposed to go back into the pool, facilitating the purchase of more assets. The initial $\$ 250$ billion can be increased to $\$ 350$ billion upon the president's certification to Congress that such an increase is necessary. The remaining $\$ 350$ billion may be released to the Treasury upon a written report to Congress from the Treasury with details of its plan for the money. Congress then has 15 days to vote to disapprove the increase before the money will be automatically released. The first $\$ 350$ billion was released on October 3, 2008, and Congress voted 
to approve the release of the second $\$ 350$ billion on January 15, 2009... On December 19, 2008, President Bush used his executive authority to declare that TARP funds may be spent on any program he personally deemed necessary to mitigate the financial crisis, and declared Section 102 to be nonbinding. This allowed Bush to extend the use of TARP funds to support the auto industry."

Liu (2009, p. 5) also stated the following concerning TARP: "The Congressional Review Panel created to oversee the TARP concluded the following on January 9, 2009: "In particular, the Panel sees no evidence that the US Treasury has used TARP funds to support the housing market by avoiding preventable foreclosures." The panel also concluded that "Although half the money has not yet been received by the banks, hundreds of billons of dollars have been injected into the marketplace with no demonstrable effects on lending."

Another part of the Treasury's Troubled Asset Relief Program was TALF (Term Asset-Backed Securities Loan Facility). The creation of TALF was announced on November 25, 2008. Under TALF, the Fed would make up to $\$ 200$ billion of loans to borrowers who bought eligible asset-backed securities (Morrison/Foerster 2008, pp. 12). These asset-backed securities were to be backed up by auto loans, student loans, credit card loans, or smallbusiness loans. The purpose of these loans was to encourage the purchase of these asset-backed securities and inject capital and liquidity into the financial system to increase lending to consumers and businesses. Morrison/Foerster (2008, p.2) also stated: "The Treasury will be providing $\$ 20$ billion of TARP funds as credit protection for the TALF."

Bloomberg News (2009, p. 1) also reported that the Fed had started to purchase mortgage-backed securities in early January 2009: "The program, initially announced Nov. 25 allows the bank to spend $\$ 500$ billion to buy mortgage-backed securities guaranteed by the mortgage-financing companies Fannie Mae and Freddie Mac and an additional $\$ 100$ billion to directly purchase mortgages held by Fannie, Freddie and the Federal Home Loan banks. The program is aimed at driving down the price of mortgages and making home loans more available." Levenson (2009, p. 12) stated the following concerning this Fed action: "Perhaps more important, mortgage interest rates have fallen sharply in response to the Fed's purchases of government agency-issued mortgage backed securities, and corporate and consumer borrowing rates fell in tandem with Treasury yields when the Fed announced its intention to purchase a large quantity of Treasury securities. The first round of auctions under the TALF program successfully bolstered activity in the market for asset-backed securities."

Were Fed and Treasury policies successful in stabilizing financial markets in the fall of 2008? The Trouble Asset Relief Program (TARP) of the Treasury Department has indeed received its share of criticism. Gandel (2009 (p.25)) stated, "Since October, the government has deposited $\$ 165$ billion into the accounts of the nation's eight largest banks. Yet those same financial firms are now worth $\$ 418$ billion less than they were four months ago. And the Congressional Budget Office estimates that the government's preferred shares are worth at least $\$ 20$ billion less." Gandel (p. 28) further stated, "TARP does nothing to patch the hole in the banking system. And it certainly doesn't do anything to encourage banks to make more loans. Yes, banks have gotten nearly $\$ 300$ billion in money from the government, and that's a lot of dough. But it's not free dough. In return for federal cash, the government has taken preferred stock shares as the firm's markers. Unlike common stock, which is the kind you or I would buy from a broker, preferreds have to eventually be paid back, so these are really loans, not additional capital."

Time Magazine (Feb. 23, 2009) stated the following about TARP and former Treasury Secretary Paulson. "Paulson was too late in battling the crisis, and letting Lehman fail was a pivotal mistake that rapidly eroded confidence. His attempt to fix the problem--a bailout that netted $\$ 700$ billion from Congress--has been a wasteful mess."

Barr (2008, p. 1) stated: "It may be years before we can judge the government's success in fighting the financial crisis... While the Treasury secretary has said repeatedly that one of his aims in deploying his $\$ 350$ billion war chest is to restore confidence in markets and financial institutions, a look at depressed stock prices and stressedout bond markets says he has yet to succeed." The stock market has shown many swings since the TARP Capital Purchase Program (TARP I) was announced on October 14, 2008. On October 15, 2008 the Dow Jones Industrial Average (DJIA) fell by 733 points, and it fell by 526 points on October 22. On October 28, 2008 it increased by 889 points and then fell by 443 points on November 6, 411 points on November 12, 427 points on November 19 and 444 
points on November 20. On December 1, 2008, the DJIA fell by 679 points.

Former U.S. Treasury Secretary, Henry Paulson stated the following about TARP in his testimony to the U.S. House of Representatives committee on financial services (network.nationalpost.com, Feb. 5, 2009).

And as you will recall, in September, after 13 months of market stress, the financial system essentially seized up and we had a system-wide crisis. Our markets were frozen, banks had pulled back very substantially from interbank lending. Confidence in our financial system and a number of our financial institutions had been seriously compromised... We needed the financial rescue package so we could intervene, stabilize our financial system, and minimize further damage to our economy. The rescue package was not intended to be an economic stimulus or an economic recovery package; it was intended to shore up the foundation of our economy by stabilizing the financial system, and it is unrealistic to expect it to reverse the damage that had already been inflicted by the severity of the crisis. During the two weeks Congress worked on the legislation, market conditions worsened significantly. Many Americans look at the stock market as an indicator of the economy, and during this period they saw tremendous volatility. The Dow Jones Industrial Averaage fell more 700 points on one single day, and over 9 percent during the two weeks the legislation was debated--stock market losses amounted to slightly more than \$2 trillion.

Recently I've been asked two questions. First, Congress gave you the authorities you requested, and the economy has only gotten worse. "What went wrong and why won't you use this authority for other industries? Second, if housing and mortgages are at the root of our economic difficulties, why aren't you addressing this? The answer to the first is that the purpose of the financial rescue legislation was to stabilize our financial system and strengthen it. It is not a panacea for all our economic difficulties...Put differently, if Congress had not given us the authority for TARP and the Capital Purchase Program and our financial system had continued to shut down, our economic situation would be far worse today. The answer to the second question is that the most important thing we can do to mitigate the housing correction and reduce the number of foreclosures is to increase access to lower cost mortgage lending. The actions we have taken to stabilize and strengthen Fannie Mae and Freddie Mac, and through them to increase the flow of mortgage credit, together with our bank capital program, are powerful actions to promote mortgage lending.

Have TARP and Fed policies stabilized financial markets? The purpose of this paper is to see if volatility in stock index returns has or has not been reduced due to the stabilization policies implemented.

In the next section, the traditional stock valuation model will be presented. It will outline the conditions under which Fed and Treasury policies may increase or decrease volatility in stock index returns.

\section{THE TRADITIONAL STOCK VALUATION MODEL}

Following the dividend-cash-flow model, a stock's price is the present value of expected future cash flows as given below.

$$
P_{t}=\frac{E\left(D_{t+1}\right)}{(1+r)^{t+1}}+\frac{E\left(D_{t+2}\right)}{(1+r)^{t+2}}+\ldots \frac{E\left(D_{T}\right)}{(1+r)^{T}}+\frac{E\left(P_{T}\right)}{(1+r)^{T}}
$$

In equation (1), $P_{t}$ is the stock's price in period $t, D_{t+k}$, is the dividend in period $t+k, E$ is the expected value operator, $\mathrm{E}\left(\mathrm{D}_{\mathrm{t+k}}\right)$, is the expected dividend in period $\mathrm{t}+\mathrm{k}, \mathrm{T}$ is the time period in which the stock is sold, $\mathrm{P}_{\mathrm{T}}$, is the price the stock is sold for in period $\mathrm{T}$, and $\mathrm{r}$ is the discount rate. Dividends per share in period $\mathrm{t}+\mathrm{k}$ are a function of profits in period $\mathrm{t}+\mathrm{k}$ of the company issuing the stock, and are modeled as follows.

$$
D_{t+k}=f\left(\pi_{t+k}\right)
$$

where $\mathrm{B}_{\mathrm{t}+\mathrm{k}}$ is profits in period $\mathrm{t}+\mathrm{k}$ and $f^{\prime}$ is assumed to be positive. Finally, expected dividends in period $\mathrm{t}+\mathrm{k}$ are 
found by taking the expected value of equation (2) resulting in equation (3).

$$
E\left(D_{t+k}\right)=f\left[E\left(\pi_{t+k}\right)\right]
$$

From equation (3), any factor affecting expected future profits of a company will affect expected future dividends and the stock's current price. On the revenue side, if investors anticipate higher consumer incomes and higher company sales in the future, expected future profits will be higher than otherwise anticipated and stock prices should increase. On the cost side, if investors anticipate credit restrictions in the future placed on companies by banks facing losses, then expected future profits will be less than otherwise anticipated and stock prices will fall. Since stock returns are percentage changes in stock prices, those same factors affecting stock prices will affect stock returns.

The Treasury Department and Federal Reserve have taken steps to inject capital into the nation's banking system. Loans have been made by the Fed to financial companies acquiring banks in distress. Preferred shares have been purchased in banks by the U.S. Treasury Department to increase bank lending. These policies should affect stock prices and returns in several ways. First, the cost of acquiring funds has been reduced to those financial companies receiving TARP funds and Fed loans. This should raise their expected profits and stock prices giving rise to positive stock returns or negative returns that are not as large as they would otherwise have been. Second, bank lending should be increased with the increase in capital to banks. This added source of funds to businesses should increase their expected profitability, share price, and stock returns. Third, these Fed and Treasury policies should affect the expectations of consumers and investors. If it is felt that positive steps are being taken to improve the nation's financial system and economic well-being, then consumer confidence along with consumer expenditures on goods and services should increase and more investors should return to equity markets. The net result should be a reduction in consumer and investor uncertainty about the future and a stabilization of stock returns (as measured by a decrease in volatility of stock index returns) following the implementation of Fed and Treasury policies. On the other hand, as the critics point out, bank lending may not increase with Fed and Treasury policies and banks may simply use the additional capital for large bonuses paid to their executives or they may simply hold on to the additional capital if there are no borrowers. Furthermore, if consumers do not expect these policies to work and improve the economic situation, then consumer confidence and spending will not increase and there will be no reduction in the volatility of stock returns.

In the next section, the data and methodology used to test the success or failure of these stabilization policies will be presented.

\section{DATA AND METHODOLOGY}

In the traditional stock valuation model of section 3, stock prices, changes in stock prices and stock returns, depend on expectations of investors of future company profits. These profits are in turn, a function of Fed and Treasury policies. Since Fed and Treasury policies occur at given points in time, they are modeled as binary independent variables: 1 on the relevant date(s) over which the policy was in effect and 0 otherwise. To estimate this stock valuation model for the overall economy, stock index returns rather than individual company returns are used as the dependent variable while binary independent variables are retained to account for Fed and Treasury policies. Stock index returns for the Dow Jones Industrial Average (DJIA), the NASDAQ and the S\&P 500 from January 5, 1999 to January 9, 2009 are shown in figures 1, 2, and 3, respectively. These daily returns $\left(\mathrm{r}_{t}\right)$ were

calculated from daily index figures $\left(\mathrm{I}_{\mathrm{t}}\right)$ using the formula, $r=\log \left(I_{t} / I_{t-1}\right)$, which gives the percent change in daily stock index figures.

In figures 1 through 3 , the amplitudes of returns vary over time with periods of high volatility followed by periods of low volatility of returns. This volatility clustering or persistence is frequently found in financial timeseries variables. Thus the stock valuation model involving stock index returns and binary independent variables, must account for such volatility clustering. This is accomplished through use of the ARCH and GARCH models. The Autoregressive Conditional Heteroskedasticity (ARCH) and Generalized Autoregressive Conditional 
Heteroskedasticity (GARCH) models were developed by Engle (1982) and Bollerslev (1986), respectively. These models have been used in the literature to determine the effects of social, economic, and political events, on the volatility of stock index returns. Examples of papers using these models include Fabozzi, Tunaru and Wu (2004), Long (2008), Lin and Wang (2005), Miles (2002), Ahmed and Farooq (2008), and Chan and Hooy (2003). The standard GARCH model for stock index returns is specified as follows:

$$
\begin{aligned}
& r_{t}=\mu+\theta r_{t-1}+\varepsilon_{t} \\
& \sigma_{t}^{2}=\omega+\alpha \varepsilon_{t-1}^{2}+\beta \sigma_{t-1}^{2}+\sum_{i=1}^{k} \lambda_{i} D_{i}
\end{aligned}
$$

\section{RETURNS}

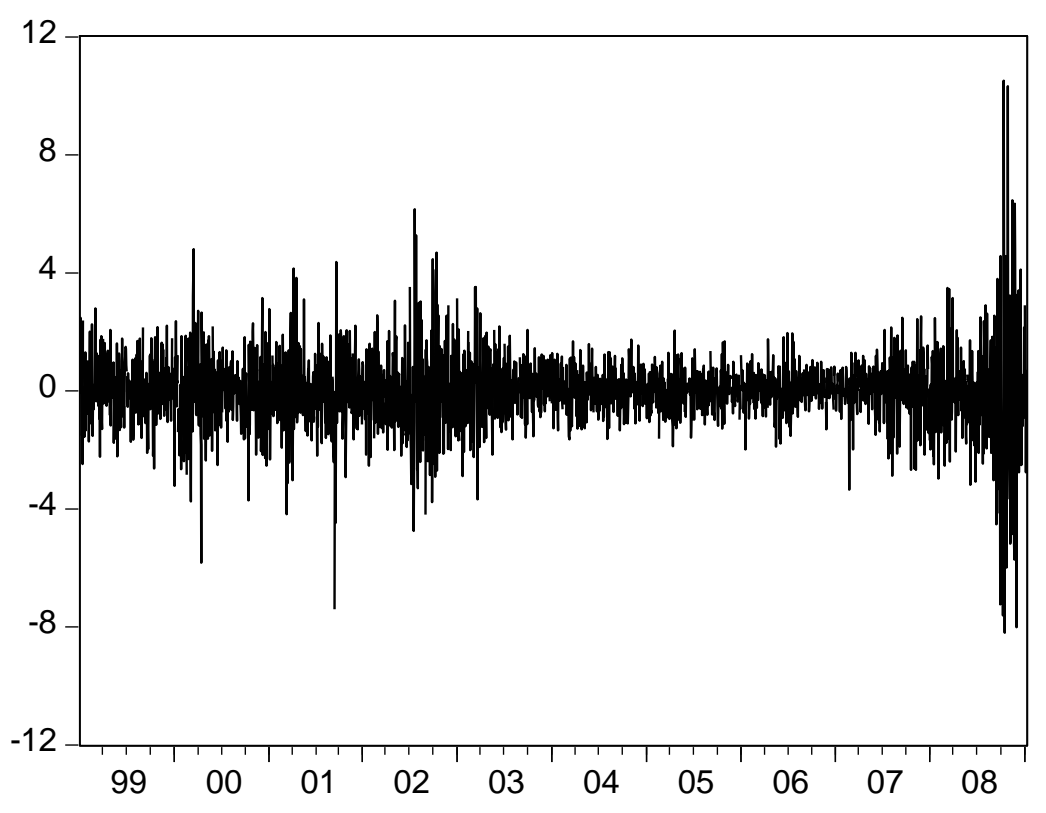

Figure 1: Daily Market Returns for the DJIA

Equation (1) of the GARCH model is referred to as the "mean equation." In this case, daily index returns $\left(\mathrm{r}_{\mathrm{t}}\right)$ are modeled as a first-order autoregressive stochastic process where $\mu$ is a constant. ${ }^{1}$ Equation (2) of the GARCH model is referred to as the "variance equation." In the $\operatorname{GARCH}(1,1)$ model, the variance of $\varepsilon_{t}$, which is designated as $\sigma_{t}^{2}$, is a function of one lagged ARCH term, $\varepsilon_{t-1}^{2}$, one lagged GARCH term, $\sigma_{t-1}^{2}$, the constant $\omega$, and $\mathrm{k}$ binary independent variables $\left(\mathrm{D}_{\mathrm{i}}\right)$ to account for Fed and Treasury policies. In this GARCH model, Fed and Treasury policies are therefore allowed to affect the variance or volatility of stock index returns through $\sigma_{t}^{2}$. The parameter $\beta$ shows the effect of volatility in the previous period on this period's volatility. The closer $\beta$ is to 1 , the more persistent is volatility in the market. The parameter $\alpha$ shows the effect of the past disturbance or shock on volatility in the present period. Furthermore, it can be shown that the model requires that $\alpha>0, \beta>0$, and $\alpha+\beta<1 .^{2}$ 


\section{RETURNS}

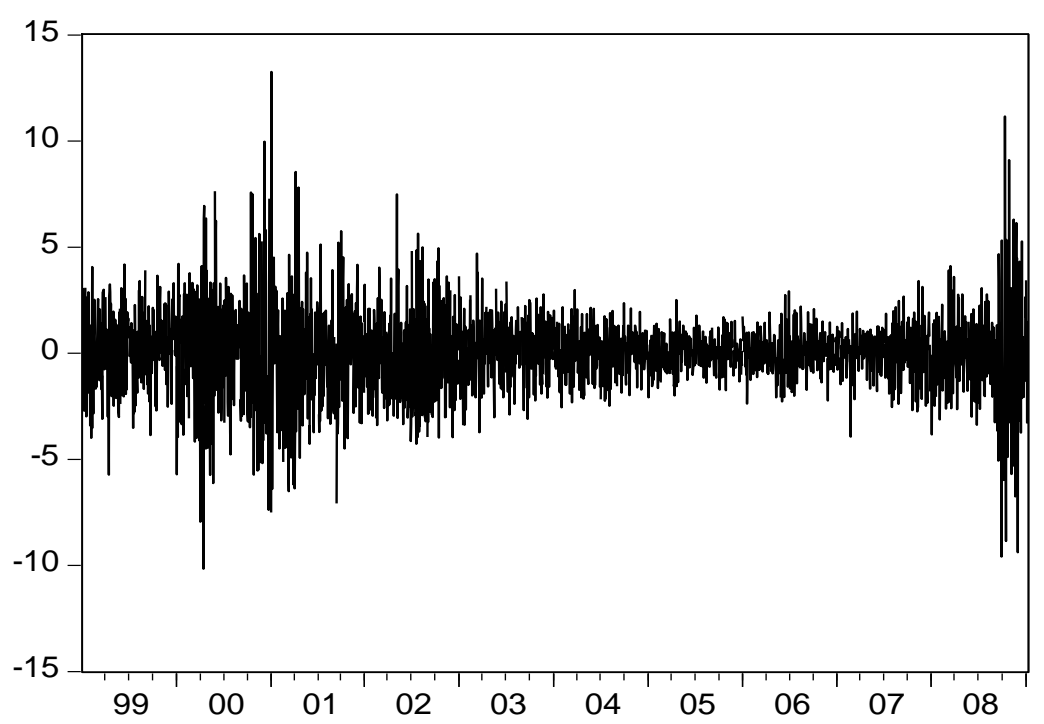

Figure 2: Daily Market Returns for the NASDAQ

RETURNS

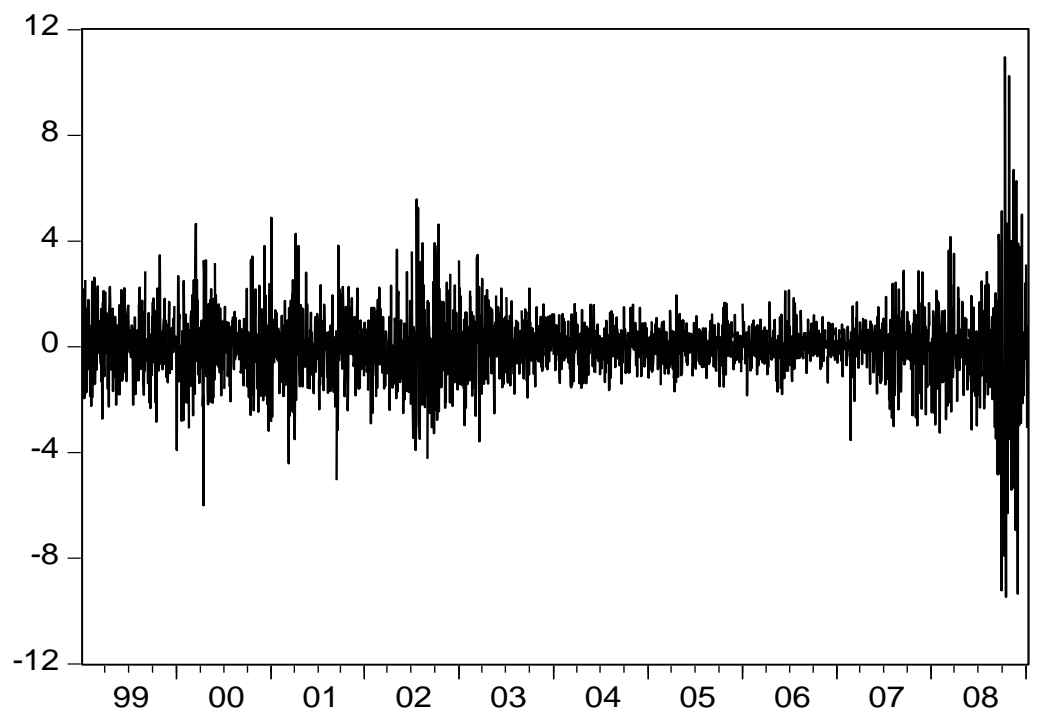

Figure 3: Daily Market Returns for the S\&P 500

Two dummy variables were selected for the variance equation. The first one, D1 was set equal to one for the dates from September 15, 2008 to January 9, 2009, the end of the data set, and set equal to 0 otherwise. As previously stated in the introduction, the financial crisis worsened in the fall of 2008 and many cited the date of September 15, 2008 as when the economy took a turn for the worse. The government did not intervene to prevent the bankruptcy of Lehman Brothers over the weekend of September 13 and 14 and on September 15, 2008 the DJIA fell by 504 points, its largest point decline in 2008 up to that date. If the coefficient of D1 in the variance equation is 
positive, then that would indicate more volatility in stock index returns in the post-September 15, 2008 market relative to the pre-September 15, 2008 period. The second dummy variable, D2, that was selected for the variance equation was set equal to one for the dates from October 14, 2008 to January 9, 2009 and zero otherwise. On October 14, 2008, the Treasury Department announced the TARP Capital Purchase Program. The first Treasury purchases of bank preferred shares took place on October 28 and continued throughout the year and into 2009. The sample estimation period ended on Friday January 9, 2009 since that date marked the end of TARP 1 with TARP 2 beginning on Monday, January 12, 2009, when President Bush asked Congress to release the remaining $\$ 350$ billion of TARP funds at the request of President-elect Obama. Thus a negative coefficient of D2 would imply that the first $\$ 350$ billion of TARP funds (TARP 1), along with Fed policy, stabilized financial markets and reduced volatility of stock index returns in the post-September 15, 2008 period. In the next section, the estimates of the GARCH model will be presented and discussed.

\section{EMPIRICAL RESULTS}

The maximum likelihood estimates of the GARCH model are given in Table 1 for stock index returns from the DJIA, the NASDAQ and the S\&P 500. ${ }^{3}$ The sample period from January 5, 1999 to January 9, 2009 contained 2,519 observations for each of the three separate models that were estimated.

In the DJIA model, $\alpha+\beta$, the sum of the coefficients of $\varepsilon_{t-1}^{2}$ and $\sigma_{t-1}^{2}$ in the variance equation, is less than, but very close to one indicating that shocks to volatility of returns are highly persistent. ${ }^{4}$ The coefficient of D1 in the variance equation was positive and significant $(+1.66)$, indicating an increase in the volatility of index returns in the post-September 15, 2008 period. The coefficient of D2 in the variance equation was negative and significant $(-1.91)$ indicating not only a decrease in the volatility of index returns in the post-September 15, 2008 period after TARP 1 was announced (October 14, 2008), but a decrease in volatility that completely offset the increase in volatility in the fall of 2008. ${ }^{5}$ This suggests that TARP 1 and Fed policies in late 2008 did help to stabilize financial markets as suggested by Treasury Secretary Paulson. The actual stock index returns from the DJIA are plotted against their fitted values from the GARCH model in figure 4.

In the NASDAQ model, the sum of the coefficients of $\varepsilon_{t-1}^{2}$ and $\sigma_{t-1}^{2}$ was again close to one indicating the high persistence of shocks to volatility of index returns. ${ }^{6}$ The coefficient of D1 in the variance equation was positive and significant $(+1.72)$ indicating an increase in index return volatility in the post-September 15, 2008 period. The coefficient of D2 was negative and significant (-2.0888) indicating a more than offsetting decrease in return volatility with the implementation of TARP 1 and Fed policies after October 14, 2008. These results support the arguments made by those who believed that such policies stabilized financial markets. ${ }^{7}$

In the S\&P 500 model, results similar to those for the DJIA and NASDAQ were obtained. The stock index return series exhibited high persistence in volatility and again the coefficients of D1 and D2 were significantly positive and negative, respectively, showing the contribution of Fed and TARP 1 policies towards stabilization in financial markets. ${ }^{8}$

\section{CONCLUSIONS}

The financial crisis of 2007-2008 which began in the summer of 2007, took a turn for the worse on September 15, 2008 with the bankruptcy of Lehman Brothers. On that date the DJIA fell by 504 points, its largest point drop in 2008 up to that day. On October 14, 2008, the Treasury announced the TARP Capital Purchase Program which would consist of Treasury purchases of preferred shares with warrants from many of the nation's largest financial institutions. These initial purchases, which some referred to as TARP 1, took place from October 28, 2008 through January 9, 2009. On Monday, January 12, 2009, President Bush requested the release of the remaining $\$ 350$ billion of TARP funds (TARP 2) from Congress, at the request of President-elect Obama. Costello (2009, p.2) stated the following concerning TARP 1: "Lawmakers from both parties have criticized Treasury Secretary Henry Paulson's decision to devote the first half of the TARP money largely to recapitalize banks as a way to lessen the worst credit crisis in a generation. Critics wanted the money used to slow the soaring rate of foreclosures." 


\begin{tabular}{|c|c|c|c|c|c|c|c|c|c|c|c|}
\hline \multicolumn{12}{|c|}{$\frac{\text { Table 1. GARCH MODELS }}{\text { Mean Equations }}$} \\
\hline \multicolumn{4}{|c|}{ DJIA } & \multicolumn{4}{|c|}{ NASDAQ } & \multicolumn{4}{|c|}{ S\&P 500 } \\
\hline $\begin{array}{l}\text { Variables } \\
\end{array}$ & Coefficient & z-statistic & $\mathrm{P}$-value & Variables & Coefficient & z-statistic & $\mathrm{P}$-value & Variables & Coefficient & z-statistic & P-value \\
\hline $\mathrm{C}$ & 0.0365 & 2.0118 & 0.0442 & $\mathrm{C}$ & 0.0398 & 1.6283 & 0.1035 & C & 0.0286 & 1.5242 & 0.1274 \\
\hline$r_{t-1}$ & -0.0450 & -2.0527 & 0.0401 & $r_{t-1}$ & -0.0257 & -1.1669 & 0.2433 & $r_{t-1}$ & -0.0572 & -2.5512 & 0.0107 \\
\hline \multicolumn{12}{|c|}{ Variance Equations } \\
\hline $\mathrm{C}$ & 0.0104 & 5.7766 & 0.0000 & $\mathrm{C}$ & 0.0070 & 2.8988 & 0.0037 & $\mathrm{C}$ & 0.0084 & 5.3321 & 0.0000 \\
\hline$\varepsilon_{t-1}^{2}$ & 0.0677 & 9.9962 & 0.0000 & $\varepsilon_{t-1}^{2}$ & 0.0464 & 6.8187 & 0.0000 & $\varepsilon_{t-1}^{2}$ & 0.0568 & 8.3995 & 0.0000 \\
\hline$\sigma_{t-1}^{2}$ & 0.9242 & 120.78 & 0.0000 & $\sigma_{t-1}^{2}$ & 0.9510 & 135.57 & 0.0000 & $\sigma_{t-1}^{2}$ & 0.9368 & 132.54 & 0.0000 \\
\hline $\mathrm{D1}^{*}$ & 1.6637 & 2.0221 & 0.0432 & D1 & 1.7204 & 2.4807 & 0.0131 & D1 & 2.0309 & 2.3235 & 0.0202 \\
\hline $\mathrm{D} 2^{* *}$ & $\begin{array}{l}-1.9140 \\
\end{array}$ & -2.2843 & 0.0224 & $\mathrm{D} 2$ & -2.0888 & $\begin{array}{l}-2.8213 \\
\end{array}$ & 0.0048 & $\mathrm{D} 2$ & -2.3785 & -2.6410 & 0.0083 \\
\hline
\end{tabular}




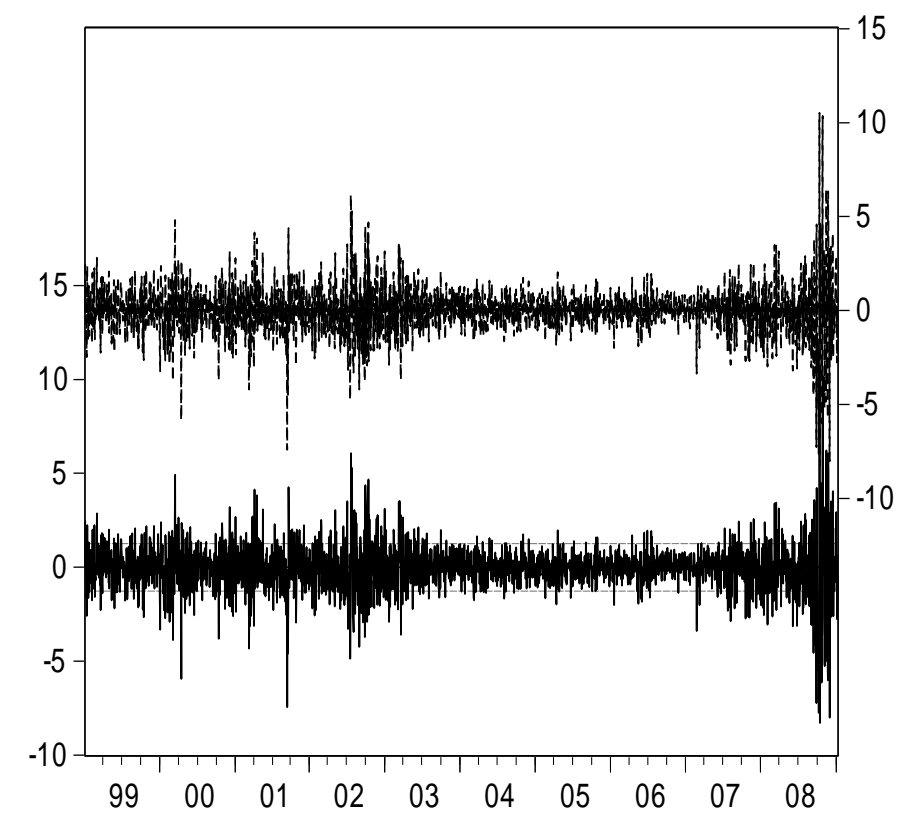

Figure 4: Actual Index Returns in Top Diagram and Fitted Index Returns in Bottom Diagram for the DJIA

The purpose of TARP 1 was to stabilize financial markets. Becketti and Sellon, (1990) gave several reasons for the goal of stabilizing financial markets when the stock market collapsed on October 19, 1987. They stated,

Much of the recent concern over financial market volatility has centered on the stock market and the collapse in stock prices that occurred on October 19, 1987. The 508-point drop in the Dow-Jones average on October 19 was the largest one-day percentage drop in history. Stock market volatility of this magnitude could harm the economy through a number of channels.

One way that stock price volatility hinders economic performance is through consumer spending. For example, immediately after the October 19 drop in stock prices, economic forecasters predicted sharply weaker economic growth. These analysts believed that the fall in stock prices would reduce consumer spending. The sizable fall in consumer wealth was expected to directly lower consumer spending. In addition, a weakening in consumer confidence could contribute to a further spending reduction.

Stock price volatility may also affect business investment spending. Investors may perceive a rise in stock market volatility as an increase in the risk of equity investments. If so, investors may shift their funds to less risky assets. This reaction would tend to raise the cost of funds to firms issuing stock. (p. 4).

To determine if TARP 1 did indeed stabilize financial markets, the traditional stock-valuation model in return form was estimated for the overall economy using stock index returns from the DJIA, the NASDAQ and the S\&P 500. Changes in Fed and Treasury policies that affect expectations of future company profits and current stock prices and returns, were modeled as dummy variables. Furthermore, since volatility in stock index returns is highly persistent, the GARCH model was used. It was found that (1) volatility of stock index returns increased in the postSeptember 15, 2008 period after the bankruptcy of Lehman Brothers. (2) Volatility in the post-September 15 period was reduced and more than offset by Fed and Treasury policies announced and implemented from October 14, 2008 to January 9, 2009. 
There is also some evidence that the positions of some financial institutions have improved to the point where they can start to pay back TARP funds to the government. A Reuters report (2009, June 8, p. 1) stated: "Some of the banks expected to get the green light to pay back TARP money include JPMorgan, American Express co., Morgan Stanley, State Street Corp and U.S. Bancorp, the New York Post said on Monday...Later this week the government is expected to disclose which of the 19 largest U.S. banks will be allowed to repay some or all of their TARP money."

The Fed and Treasury have indeed been involved with many policies to stimulate the economy, create jobs and make loans available for consumers and businesses. Some of these policies included TARP 1, TARP 2, TALF, the American Recovery and Reinvestment Act, stress tests for financial institutions to see if they could sustain losses from a worsening economy, and the Public-Private Investment Program, part of which involves an expansion of TALF (the Term Asset-Backed Securities Loan Facility). The combination of these policies may be what is needed to bring the financial crisis to an end.

\section{NOTES}

1. The exact specification of the "mean equation" depends upon the autoregressive structure of the index return series. This will be determined in section 5, "empirical results".

2. For the unconditional variance to exist, this condition must be satisfied. See Davidson and MacKinnon (2004, p. 589).

3. In estimating the GARCH model, the likelihood function that is maximized is:

$$
\begin{aligned}
& \ln L=-\frac{T}{2} \ln (2 \pi)-\frac{T}{2} \ln \sigma_{t}^{2}-\frac{1}{2} \sum_{t=1}^{T} \frac{\varepsilon_{t}^{2}}{\sigma_{t}^{2}}, \text { where } \mathrm{T} \text { is the total number of observations and } \\
& \sigma_{t}^{2}=\varpi+\alpha \varepsilon_{t-1}^{2}+\beta \sigma_{t-1}^{2}+\sum \lambda_{i} D_{i} .
\end{aligned}
$$

4. To test if the mean equation was correctly specified (the DJIA index return series was specified using a first-order autoregressive process), the correlogram of standardized residuals was analyzed. All of the Qstatistics were insignificant, indicating a correctly specified mean equation. To test if the variance equation was correctly specified the correlogram of squared standardized residuals was examined. All of the Qstatistics were insignificant at the $5 \%$ level indicating a correctly specified variance equation.

5. The GARCH model was also estimated when the dummy variable, D2, was 1 for the dates from October 28, 2008 to January 9, 2009, and 0 otherwise. October 28 was the date when the first TARP 1 purchases took place which was 14 days after the announcement date. The results of the GARCH model were very similar to those using the announcement date.

6. To test if the mean equation for the NASDAQ model was correctly specified, the correlogram of standardized residuals was analyzed. All of the Q-statistics were insignificant, indicating a correctly specified mean equation.

7. To test if the variance equation for the NASDAQ model was correctly specified, the correlogram of the squared standardized residuals was examined. Some of the Q-statistics were significant, indicating remaining $\mathrm{ARCH}$ in the variance equation. Thus the variance equation for the NASDAQ model was reestimated using two ARCH effects and one GARCH effect. The results are given below: 


\section{$\underline{\text { Mean Equation }}$}

\begin{tabular}{|c|c|c|c|}
\hline$\frac{\text { Variable }}{\mathrm{C}}$ & $\frac{\text { Coefficient }}{0.0389}$ & $\frac{\text { z-statistic }}{1.5971}$ & $\frac{\text { P-value }}{0.1102}$ \\
\hline \multirow[t]{2}{*}{$r_{t-1}$} & -0.0344 & -1.9307 & 0.0535 \\
\hline & \multicolumn{3}{|c|}{ Variance Equation } \\
\hline Variable & Coefficient & $\underline{\text { Z-statistic }}$ & $\underline{\text { P-value }}$ \\
\hline $\mathrm{C}$ & 0.0104 & 3.2209 & $\overline{0.0013}$ \\
\hline$\varepsilon_{t-1}^{2}$ & -0.0290 & -3.1582 & 0.0016 \\
\hline$\varepsilon_{t-2}^{2}$ & 0.0930 & 7.1927 & 0.0000 \\
\hline$\sigma_{t-1}^{2}$ & 0.9326 & 102.89 & 0.0000 \\
\hline D1 & 1.9252 & 2.1650 & 0.0304 \\
\hline D2 & -2.2971 & -2.4861 & 0.0129 \\
\hline
\end{tabular}

The coefficient of D1 is still positive and significant and the coefficient of D2 is still negative and significant which reinforces the results in Table 1. The correlogram of squared standardized residuals for this model were then analyzed. The Q-statistics were all insignificant indicating a correctly specified variance equation.

8. To test if the mean equation for the S\&P 500 model was correctly specified, the correlogram of standardized residuals was examined. All of the Q-statistics were insignificant indicating a correctly specified mean equation. To test if the variance equation was correctly specified, the correlogram of squared standardized residuals was examined. All of the Q-statistics were insignificant at the 5\% level, indicating a correctly specified variance equation.

\section{AUTHOR INFORMATION}

Anh Nguyen received a Master of Arts degree in Economics at New Mexico State University in 2009. Growing up in Vietnam, she studied mathematics, physics and economics and she received a Bachelors Degree in Foreign Trade Economics at the Foreign Trade University in Hanoi. Her research interests include options pricing and applications of the Garch model.

Carl Enomoto is a Professor of Economics at New Mexico State University where he has been teaching for 26 years. He received his Ph.D. in Economics from Texas A\&M University in December, 1982. His research interests include macroeconomics, current social issues, mathematical models and econometrics.

\section{REFERENCES}

1. Ahmed, Sheraz and Farooq, Omar. 2008. The effect of 9/11 on the stock market volatility dynamics: Empirical evidence from a front line state. International Research Journal of Finance and Economics, 16, 71-83.

2. Barr, Colin. 2008. A TARP report card: Treasury scores an A for effort in the financial rescue, but observers give in middling marks otherwise. Available at: http://cnnmoney.printthis.clickabilityk.com/pt/cpt?.action=cpt\&title=Mixed+grades+for

3. Becketti, Sean, and Gordon H. Sellon, Jr. 1990. Has financial market volatility increased? In Financial Market Volatility and the Economy. Federal Reserve Bank of Kansas City. 
4. Bernanke, Ben S. 2009. The Federal reserve's balance sheet. Available at: www.federalreserve.gov/newsevents/speech/bernanke20090403a.htm.

5. Block, Sanda. 2008. What's next for bank customers at failed Washington Mutual? Available at: http://www.usatoday.com/money/perf/basics/2008-09-28-wamu-jpmorgan-chase_N.htm.

6. Bloomberg News. 2009. New York fed starts buying mortgage-backed securities. Available at: www.iht.com/articles/2009/01/05/business/fed.php.

7. Bollerslev, Tim. 1986. Generalized autoregressive conditional heteroskedasticity. Journal of Econometrics, 31 (3), 307-327.

8. Brownell, Charles. 2008. Subprime meltdown: From U.S. liquidity crisis to global recession. United States.

9. Chan, Tze-Haw, and Chee w. Hooy. 2003. On volatility spillovers and dominant effects in east asia; Before and after 9/11. Available at http://mpra.ub.uni-muenchen.de/2032/.

10. Costello, Daniel. 2009. Financial bailout shifting to main street? Available at: www.npr.org/templates/story/story.php?storyId=99385376.

11. Davidson, Russell and James G. MacKinnon. 2004. Econometric theory and methods. New York, NY: Oxford University Press, Inc.

12. Engel, Robert F. 1982. Autoregressive conditional heteroscedasticity with estimates of the variance of United Kingdom inflation. Econometrica, 50 (4), 987-1007.

13. Fabozzi, Frank J., Radu Tunaru, and Tony Wu. 2004. Modeling volatility for the Chinese equity markets. Annals of Economics and Finance, 5, 79-92.

14. Foster, John B. and Fred Magdoff. 2009. The Great financial crisis. New York, NY: Monthly Review Press.

15. Gandel, Stephen. 2009. Why your bank is broke. Time magazine, February 9, 2009, pp. 25-28.

16. Gorman, Cheryl A. 2008. US Treasury capital purchase program: The intended and unintended consequences. Available at www.gibbonslaw.com/news_publications/articles.php?action=display_publication

17. Holmes, Steven A. 1999. Fannie Mae eases credit to aid mortgage lending. Available at: www.nytimes.com/1999/09/30/business/fannie-mae-eases-credit-to-aid-mortage-lending.

18. Horsley, Scott. 2009. President Bush petitions for rest of bailout funds. Available at: www.npr.org/templates/story/story.php?storyId=99276452.

19. Karnitschnig, Deborath S., Liam Pleven, and Jon E. Hilsenrath. 2008. U.S. to take over AIG in \$85 billion bailout; Central banks inject cash as credit dries up. Available at: www.badfaithinsurance.org/reference/General/0614a.htm.

20. Krugman, Paul. 2009. The Return of depression economics and the crisis of 2008. New York, NY: W.W. Norton \& Company Ltd.

21. Lazzaro, Joseph. 2009. Tarp I, if nothing else, bought time for TARP II. Available at www.bloggingstocks.com/2009/02/03/tarp-i-if-nothing-else-boutht-time-for tarp -ii/.

22. Levenson, Alan. 2009. Unprecedented policies steering economy back to growth. In T. Rowe Price Report. Issue No. 103, Spring 2009.

23. Lin, Chin-Tsai, and Wang, Yi-Hsien. 2005. An analysis of political changes on Nikkei 225 stock returns and volatilities. Annals of Economics and Finance, 6, 169-183.

24. Liu, Henry C.K. 2009. The Burden of elitism. Available at: www.atimes.com/atimes/printN.html.

25. Long, Vuong T., 2008. Empirical analysis of stock return volatility with regime change using garch model: The case of Vietnam stock market. Working paper 084. Available at: www.vdf.org.vn/workingpapers/vdfwp084.

26. Miles, William. 2002. Financial deregulation and volatility in emerging equity markets. Journal of Economic Development, 27 (2), 113-126.

27. Morrison \& Foerster. 2008. TARP's term asset-backed securities loan facility: Can wall street help main street? Available at: www.mofo.com/news/updates/files/081126TermAsset.pdf

28. Muolo, Paul. 2009. \$700 Billion bailout: The emergency economic stabilization act and what it means to you, your money, your mortgage, and your taxes. Hoboken, NJ: John Wiley \& Sons, Inc.

29. Paulson, Henry. 2008. Testimony to Congress: TARP is not a "panacea." Available at: http://network.nationalpost.com/np/blogs/fpposted/archive/2008/11/18/paulson-testimony 
30. Reuters. 2009. Goldman, JPMorgan may get OK to repay TARP: reports. Available at: www.reuters.com/articlePrint?articleID=USTRE5572CF20090608.

31. Shiller, Robert J. 2008. The Subprime solution. Princeton, NJ: Princeton University Press.

32. Soros, George. 2008. The New paradigm for financial markets: The credit crisis of 2008 and what it means. Philadelphia, PA: Public Affairs.

33. Taylor, John B. 2008. The Financial crisis and the policy responses: An Empirical analysis of what went wrong. Available at: www.stanford.edu/ johntayl/FCPR.pdf.

34. Time Magazine. 2009. 25 people to blame: The good intentions, bad managers and greed behind the meltdown. February 23, p. 22.

35. Waggoner, John. 2008. Bailout: what the rescue of Bear Stearns and the credit crisis mean for your investments. Hoboken, NJ: John Wiley \& Sons, Inc.

36. Zandi, Mark. 2008. Financial Shock: A $360^{\circ}$ look at the subprime mortgage implosion, and how to avoid the next financial crisis. Upper Saddle River, NJ: Pearson Education, Inc. 
NOTES 